\title{
Microbiological Findings in Deep Caries Lesions
}

\author{
Irena Kuzmanović Radman ${ }^{1}$, Aleksandra Djeri', Adriana Arbutina², Jelena Milašin ${ }^{3}$ \\ 'Department of Dental Diseases, Faculty of Medicine, Study Program Dentistry, University of Banja Luka, Banja Luka, \\ Republika Srpska, Bosnia and Herzegovina; \\ 2Department of Orthodontics, Faculty of Medicine, Study Program Dentistry, University of Banja Luka, Banja Luka, \\ Republika Srpska, Bosnia and Herzegovina; \\ ${ }^{3}$ University of Belgrade, Faculty of Dental Medicine, Belgrade, Serbia
}

\begin{abstract}
SUMMARY
Introduction Caries is one of the most significant and widespread oral diseases. It has been confirmed that dental plaque, i.e. microorganisms in it, are the most important factor in the development of dental caries. Caries profunda represents deep carious lesion from where bacterial toxins may affect pulp through dentinal tubules. The aim of this study is to assess the efficacy of indirect pulp capping based on microbiological findings of bacteria present in deep carious lesions before and after the treatment.

Material and Methods The clinical study included 29 patients of both genders, aged 16 to 40 and 45 permanent teeth with deep caries lesions. The first microbiological sample was taken after cavity preparation and removal of soft dentin from the bottom of the cavity. The second sample was taken after the removal of temporary filling and calcium hydroxide paste 60 days after the indirect pulp capping treatment. The collected samples were stored in special sterile micro tubes (Eppendorf) and kept at the temperature of $-80^{\circ} \mathrm{C}$ until microbiological analysis was performed. Samples were tested for the presence of the following microorganisms: Porphyromonas gingivalis, Aggregatibacter actinomycetemcomitans and Enterococcus faecalis using the multiplex polymerase chain reaction (PCR) method.

Results The results showed that prior to the treatment of deep carious lesions the most common species was $E$. faecalis ( $80 \%$ of samples), followed by A. actinomycetemcomitans ( $32 \%$ of samples), while the least common was $P$. gingivalis ( $16 \%$ of samples). After the treatment with products based on calcium hydroxide, E. faecalis was registered in $18 \%$ of samples, A. actinomycetemcomitans in $16 \%$ of samples and P. gingivalis was not registered in any sample.

Conclusion The most common bacterial species in teeth with deep caries lesions was E. faecalis, whereas A. actinomycetemcomitans and $P$. gingivalis were found in lower number of samples.

Keywords: deep caries lesions; bacteria; indirect pulp capping
\end{abstract}

\section{INTRODUCTION}

Dental caries is surely one of the most significant oral diseases and it is widespread both in children and adults [1, $2,3]$. Caries profunda (deep caries lesion) is the place from where bacterial toxic agents through dentinal tubules can compromise pulp causing minor or major changes in it. If bacteria are removed or "captured" in the cavity after restoration caries lesion will stop spreading. Tubular sclerosis and tertiary dentin limit bacterial nutrition from pulp due to lower dentin permeability. It has also been known that microorganisms trapped in the cavity can change and become less pathogenic [4].

It has been confirmed that dental plaque (biofilm) and microorganisms in it are the most important factors in the development of dental caries. Due to the complex etiology and pathogenesis of this disease, its treatment still poses significant problem for most dental practitioners. In addition to S. mutans, Lactobacillus spp. and Actinomyces spp. pyogenic bacteria such as Porphyromonas gingivalis, Prevotella intermedia and Aggregatibacter actinomycetemcomitans can be detected in dental plaque [5].
Viola et al. [6] analyzed saliva samples from children with and without present caries lesions and found that caries lesion starts when glucose glucan polymer (produced by S. mutans) forms a biofilm on teeth to which other oral bacteria, food debris and saliva components adhere. Ito et al. [7] using different methodology confirmed this finding. Do et al. [8] found that $S$. mutans is the most common cause of dental caries. Kouidhi et al. [9] in their study confirmed the presence of enterococci in the oral cavity of children in Tunisia. They isolated $33.9 \%$ of enterococci out of all positive cocci identified in oral cavity. $55.8 \%$ of detected enterococci were isolated from carious lesions and only $2 \%$ were found in oral cavity of children who had no caries lesions.

In order to preserve pulp vitality and successfully treat deep caries lesions, timely and proper diagnosis is necessary as well as fast and efficient removal of carious dentin (as a primary reservoir of microorganisms), application of appropriate medications and sealed restoration [10]. Pharmacological agents used in the treatment of deep caries lesions must eliminate remaining bacteria but also stimulate odontoblasts to produce tertiary dentin. Products based on 


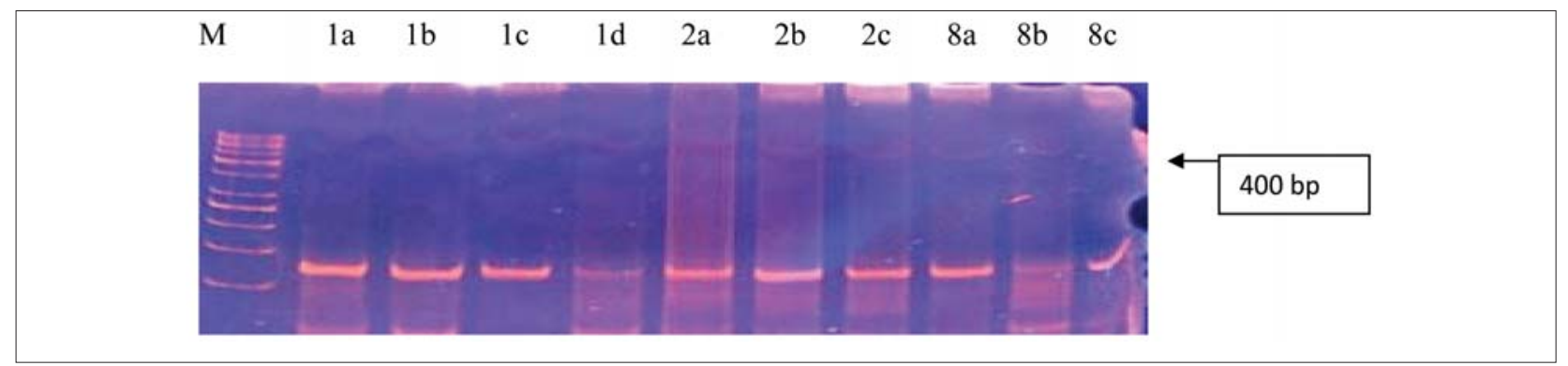

Figure 1. PAA gel with PCR results of 10 samples from three patients. The strip at hight of 400 base pairs (bp) corresponds to Enterococcus faecalis.

Slika 1. PAA gel sa PCR proizvodima 10 uzoraka poreklom od tri pacijenta. Traka na visini od 400 baznih parova (bp) odgovara bakteriji Enterococcus faecalis.

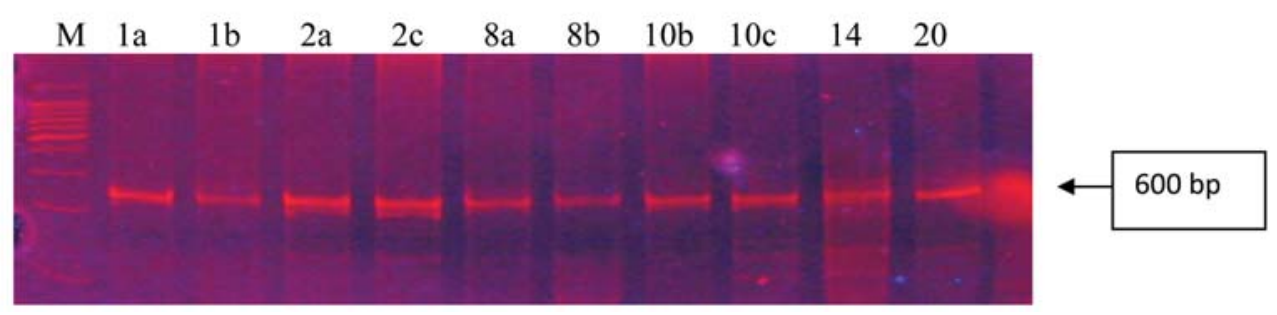

Figure 2. PAA gel with the PCR products of 10 teeth samples collected from ten patients. The strip at a height of 660 base pairs (bp) corresponds to Aggregatibacter actinomycetemcomitans.

Slika 2. PAA gel sa PCR proizvodima 10 uzoraka zuba poreklom od deset pacijenata. Traka na visini od 660 baznih parova (bp) odgovara bakteriji Aggregatibacter actinomycetemcomitans.

calcium hydroxide are the most commonly used agents in the treatment of deep caries lesions although in the last few years the use of MTA is increasing with very high success rate [11]. When applied at the bottom of clean cavity these materials stimulate odontoblasts to produce reparative dentin but also kill the remaining bacteria.

There is no consensus on the treatment of deep caries lesions. Some authors suggest complete removal of carious dentin prior to the application of medicaments while others recommend leaving a thin layer of dentin at the bottom of prepared cavity. Despite numerous achievements in modern dentistry and large number of pharmacological agents used in the treatment of caries profunda, successful treatment of deep caries lesions still depends on a number of factors $[4,12,13,14]$.

The aim of this study is to assess the efficacy of indirect pulp capping based on microbiological findings in deep carious lesions before and after the treatment.

\section{MATERIAL AND METHODS}

The clinical study included 29 patients of both genders, age 16 to 40 years, who had deep caries lesions present based on medical history, clinical and radiographic examination of 45 teeth. Each patient had assigned a special card where personal data, teeth status, precise data on medication and materials, presence of bacteria in collected samples and subjective and objective changes during the treatment protocol were recorded.

The first microbiological samples were collected after cavity preparation and removal of soften dentin from the bottom of the cavity. Using sterile cotton swab and sterile forceps samples were collected from each caries lesion and then stored in special sterile micro tubes (Eppendorf) with $150 \mathrm{ml}$ of carrier liquid and kept at $-80^{\circ} \mathrm{C}$ until microbiological analysis. Using random selection method, after removing carious dentin calcium hydroxide agent (Dycal, DENTSPLY, Germany, or Calcipupe, Septodont, France) was applied and temporary filling placed (phosphate cement, Galenika, Serbia) for a period of two months. Two months later, the temporary filling and calcium hydroxide were removed from the cavity and from the bottom of the cavity another microbiological sample was taken with a sterile cotton swab and sterile forceps.

Bacterial DNA was isolated by treating the samples with proteinase $\mathrm{K}$ at the temperature of $56^{\circ} \mathrm{C}$ for $30 \mathrm{~min}$ utes, followed by enzyme inactivation by heating the samples at the temperature of $94^{\circ} \mathrm{C}$ for 15 minutes. Then after samples were kept at $-20^{\circ} \mathrm{C}$ until PCR analysis was performed. The presence of the following microorganisms: Porphyromonas gingivalis, Aggregatibacter actinomycetemcomitans and Enterococcus faecalis was analyzed. For PCR analysis a known primer sequences were used.

\section{RESULTS}

The analysis of microorganisms in biological samples collected from 45 teeth (where the number of analyzed teeth per patient varied from 1 to 4 ) showed that the most common species was E. faecalis (80\%), followed by A. actinomycetemcomitans (32\%) while the least frequent was P. gingivalis (16\%).

The existence of electrophoretic strips of the expected length on the polyacrylamide gel indicated positive result 
Table 1. Presence of the three tested microorganisms in collected samples

Tabela 1. Učestalost tri ispitivana mikroorganizma kod pacijenata

\begin{tabular}{|c|c|c|}
\hline $\begin{array}{l}\text { Patient } \\
\text { Pacijent }\end{array}$ & $\begin{array}{c}\text { Gender } \\
\text { Pol }\end{array}$ & $\begin{array}{c}\text { First sample } \\
\text { Bris }\end{array}$ \\
\hline 1 & $F / Z ̌$ & $\mathrm{Pg}, \mathrm{Aa}, \mathrm{Ef}$ \\
\hline 2 & $F / Z \check{Z}$ & $\mathrm{Pg}, \mathrm{Aa}, \mathrm{Ef}$ \\
\hline 3 & $F / Z ̌$ & - \\
\hline 4 & $F / Z ̌$ & $\mathrm{Aa}$ \\
\hline 5 & $F / Z \check{Z}$ & $\mathrm{Pg}, \mathrm{Aa}, \mathrm{Ef}$ \\
\hline 6 & $F / Z \check{Z}$ & - \\
\hline 7 & $F / Z ̌$ & $\mathrm{Pg}$ \\
\hline 8 & $F / Z ̌$ & - \\
\hline 9 & $F / Z \check{Z}$ & - \\
\hline 10 & $F / Z ̌$ & $\mathrm{Aa}, \mathrm{Pg}$ \\
\hline 11 & $F / Z \check{Z}$ & - \\
\hline 12 & $F / Z \check{Z}$ & - \\
\hline 13 & $F / Z \check{Z}$ & - \\
\hline 14 & $F / Z \check{Z}$ & - \\
\hline 15 & $F / Z ̌$ & - \\
\hline 16 & $F / Z ̌$ & - \\
\hline 17 & $F / Z \check{Z}$ & - \\
\hline 18 & $M / M$ & Ef \\
\hline 19 & $M / M$ & - \\
\hline 20 & $M / M$ & - \\
\hline 21 & $M / M$ & - \\
\hline 22 & $M / M$ & $\mathrm{Aa}$ \\
\hline 23 & $M / M$ & - \\
\hline 24 & $M / M$ & $\mathrm{Aa}, \mathrm{Ef}$ \\
\hline 25 & $M / M$ & - \\
\hline 26 & $M / M$ & - \\
\hline 27 & $M / M$ & $\mathrm{Pg}$ \\
\hline 28 & $M / M$ & $\mathrm{Aa}$ \\
\hline 29 & $M / M$ & - \\
\hline
\end{tabular}

$\mathrm{Pg}$ - Porphyromonas gingivalis, Aa - Aggregatibacter actinomycetemcomitans; Ef - Enterococcus faecalis

$\mathrm{F}$ - female; $\mathrm{M}$ - male

Ž - ženski; $M-$ muški

Table 2. Presence of certain microorganisms before and after applied treatment

Tabela 2. Učestalost pojedinih mikroorganizama pre i posle primenjene terapije

\begin{tabular}{|l|c|c|c|c|}
\hline \multirow{2}{*}{$\begin{array}{l}\text { Bacterial species } \\
\text { Vrsta bakterije }\end{array}$} & $\begin{array}{c}|c| \\
\text { Before } \\
\text { treatment } \\
\text { Pre terapije }\end{array}$ & $\begin{array}{c}\text { After } \\
\text { treatment } \\
\text { Posle terapije }\end{array}$ & \multirow{2}{*}{$\chi^{2}$} & P \\
\hline $\begin{array}{l}\text { Aggregatibacter } \\
\text { actinomycetemcomitans }\end{array}$ & $14(32 \%)$ & $7(16 \%)$ & 1.28 & 0.185 \\
\hline $\begin{array}{l}\text { Porphyromonas } \\
\text { gingivalis }\end{array}$ & $7(16 \%)$ & $0(0 \%)$ & & 0.001 \\
\hline Enterococcus faecalis & $35(80 \%)$ & $8(18 \%)$ & 10.62 & $<0.001$ \\
\hline
\end{tabular}

for the tested species. Figure 1 shows gel with selected samples of $E$. faecalis. It is clear that one patient had $E$. faecalis detected in all 4 tested teeth $(1 \mathrm{a}, 1 \mathrm{~b}, 1 \mathrm{c}, 1 \mathrm{~d})$ but the $1 \mathrm{~d}$ sample probably had smaller count of bacteria (PCR is only a semi-quantitative technique). Another patient (2a, $2 \mathrm{~b}, 2 \mathrm{c})$ also had this species detected in all three teeth. In one case $(8 \mathrm{a}, 8 \mathrm{~b}, 8 \mathrm{c}) \mathrm{E}$. faecalis was only detected in only one sample (8b).

Figure 2 shows a polyacrylamide gel with selected samples positive for A.actinomycetemcomitans. The level of amplification was fairly uniform which is uncommon for PCR reactions on bacteriological isolates from teeth.

More than one third of patients showed the presence of some of the tested bacteria (17 out of 29 patients) (Table 1). Three patients had co-infection of all three species E. faecalis, A. actinomycetemcomitans and P. gingivalis. Interestingly, all three patients were female. In addition, two patients had $E$. faecalis and A. actinomycetemcomitans and one patient had $P$. gingivalis and A. actinomycetemcomitans as well as E. faecalis and $P$. gingivalis.

Two months after the treatment of deep caries lesions the incidence of all three microorganisms in collected samples decreased significantly. The number of samples positive to E. faecalis (16\%) and P. gingivalis (0\%) was significantly lower that before the treatment $(\mathrm{p}<0.05)$, while the number of samples positive to A. Actinomycetemcomitans was not significantly different from before the treatment (Table 2).

\section{DISCUSSION}

Dental caries is one of the most significant and most widespread oral diseases. Due to its very complex etiology and pathogenesis, the treatment outcome is often uncertain.

Bjørndal et al. [15] in their study done on 314 patients at the Faculty of Dentistry in Copenhagen found that deep caries lesions more frequently affected posterior teeth compared to anterior teeth. In agreement with this study Ahmad et al. [1] revealed that out of 204 teeth with deep caries lesions 21 teeth were incisors and 183 were posterior teeth.

Maeda et al. [16] investigated the influence of oral streptococci and lactobacilli on $\mathrm{pH}$ levels in active caries lesions on 24 extracted human molars and concluded that $\mathrm{pH}$ value of carious dentin was lower than $\mathrm{pH}$ value of intact dentin. They also concluded that there was a significant correlation between decreasing $\mathrm{pH}$ and demineralization in active caries lesions. Using the PCR method and $\mathrm{pH}$ imaging microscope, Maeda et al. found that the lowest $\mathrm{pH}$ value was registered in dentin samples affected by active caries lesions where $S$. mutans and other oral bacteria were detected. In 7 out of 8 samples with the lowest $\mathrm{pH}$, the authors detected $S$. mutans only, which is the most important species in forming biofilm and starting dentin destruction [16].

Estrela et al. [11] examined the effect of several agents used in the treatment of deep caries lesions. They found that MTA, Portland cement, Dycal, calcium hydroxide paste and Sealapeax have antibacterial effect against several bacterial species (Enterococcus faecalis, Pseudomonas aeruginosa, Bacillus subtilis, Staphylococcus aureus) and fungi (Candida albicans). After two-day incubation period calcium hydroxide paste showed the best antimicrobial effect (inhibition zone was 6 to $9.5 \mathrm{~mm}$ and diffusion zone 10-18 mm). Results for Dycal showed no inhibition zone, nor diffusion zone, which indicated weak antimicrobial activity. In 2010 Parolia et al. [12] in their study on 36 premolars confirmed the results of previous authors. 
Good adhesion to the walls of the cavity physically prevents penetration of bacteria toward the pulp and is an important prerequisite for the success of the indirect pulp capping treatment. However, as there is no material that provides an adequate marginal seal, it is very important that restorative procedure uses materials with good adhesive properties and restoration techniques that will ensure good adhesive bond of material with the cavity walls.

Pyogenic bacteria such as $P$. gingivalis, $P$. intermedia and A. actinomycetemcomitans have also been detected in dental plaque $[18,19]$. In addition to the anaerobic cultivation of microorganisms, PCR techniques (such as hybridization technique) have been used for bacterial identification [5]. Martin et al. [20] using PCR method performed microbiological analysis of 65 teeth with deep caries lesions and inflamed pulp and found that anaerobic bacteria play an important role in development of caries lesions and endodontic infections. Kneist et al. [21] analyzed bacteria found in caries lesions of primary teeth after chemical-mechanical method (CARISOLV ${ }^{\mathrm{m}}$ system) was used for caries removal. They found that number of bacteria in deep caries lesions was significantly higher than in superficial lesions (caries media). Also, their study showed that most commonly found bacteria in prepared cavity were oral streptococci (S. mutans, S. intermedia etc.) then Actinomyces spp. and Lactobacillus spp. [21].

Aas et al. [22] conducted a study on 90 patients (51 with deep caries lesions and diagnosed pulpitis). Microbiological and PCR methods reveled the presence of anaerobic bacteria while Veillonella, Lactobacillus, Bifidobacterium and Propionibacterium, Actinomyces spp., and Atopobium spp, with S. mutans, played an important role in the progression of caries lesions. Using PCR method on 20 samples of dental plaque in subjects of different ages (children aged 5 to 6 and adults), Cheon et al. [23] found that large number of genotypes of $S$. mutans (ranging from 1.6 to 2.4) were more prevalent in children than in adults.

Duque et al. [24] examined the effects of glass ionomer cement (Fuji) and Dycal in the treatment of deep caries lesions in 27 permanent molars. PCR method confirmed the presence of $S$. mutans and Lactobacillus spp. before and 3 months after the treatment of deep caries lesions. However, there was a significant reduction in the number of these bacteria after completed treatment.

It has been confirmed that $90 \%$ of enterococcal infections in humans are caused by $E$. faecalis. This species can survive in extremely difficult conditions, as it is adaptable to different environmental conditions. It can also become resistant to the lethal dose of hydrogen peroxide, ethanol and $\mathrm{pH}$ changes. Studies of Perez et al. [25] and Love et al. [26] showed that E. faecalis can be found in dentinal tubules of teeth with caries lesions. Kayaoglu and Ørstavik [27] pointed out the significance of E. faecalis in the occurrence of endodontic disease and periapical inflammation. Kolenbrander et al. [28] found A. actinomycetemcomitans and P. gingivalis to be one of the most significant bacteria in the development of caries lesions [26]. Gomez et al. [29] examined the efficacy of chlorhexidine and calcium hydroxide against $E$. faecalis and found that chlorhexidine completely inhibited its growth while calcium hydroxide had no effect.

The most commonly detected species in caries lesions prior to the treatment in the current study was $E$. faecalis, followed by A. actinomycetemcomitans while the least common was $P$. gingivalis. After the treatment with calcium hydroxide products, there was a significant reduction in the number of $E$. faecalis and A. actinomycetemcomitans, while $P$. gingivalis was not detected in any samples. This can be explained by the fact that $E$. faecalis was probably effectively mechanically removed using burs or it diffused into dentinal tubules. Another reason why it was not detected could be a good marginal seal achieved with phosphate cement after application of calcium hydroxide medicaments during 60 days. Considering that medicaments based on calcium hydroxide do not have killing effect on E. faecalis, its decrease was probably due to the correct mechanical removal of caries and good restorative filling done by the same practitioner in adequate clinical conditions. Remaining E. faecalis in deeper layers of dentinal tubules and inefficient removal of carious dentin may be reasons for failure of indirect pulp capping, which consequently can lead to inflammation of the pulp and need for endodontic treatment.

\section{CONCLUSION}

Prior to the treatment of deep caries lesions the most commonly detected bacterial species was E. faecalis, followed by A. actinomycetemcomitans while the least common was $P$. gingivalis. After indirect pulp capping, $E$. faecalis and A. actinomycetemcomitans were detected in significantly smaller number of samples while P. gingivalis was not found in any sample.

\section{REFERENCES}

1. Al-Hiyasat AS, Barrieshi-Nusair KM, Al-Omari MA. The radiographic outcomes of direct pulp-capping procedures performed by dental students: a retrospective study. J Am Dent Assoc. 2006; 137:1699-705. [DOI: 10.14219/jada.archive.2006.0116] [PMID: 17138715]

2. Costa CA, Giro EM, Nascimento AB, Teixeira HM, Hebling J. Short term evaluation of the pulpo-dentin complex response to a resinmodified glass-ionomer cement and a bonding agent applied in deep cavities. Dent Mater. 2003; 19:739-46. [DOl: 10.1016/S0109-5641(03)00021-6] [PMID: 14511732]

3. Kuratate M, Yoshiba K, Shigetani Y, Yoshiba N, Ohshima H, Okiji T. Immunohistochemical analysis of nestin, osteopontin, and proliferating cells in the reparative process of exposed dental pulp capped with mineral trioxide aggregate. J Endod. 2008; 34:970-4. [DOI: 10.1369/0022155411403314] [PMID: 18634929]

4. Casagrande L, Bento LW, Dalpian DM, García-Godoy F, de Araujo FB. Indirect pulp treatment in primary teeth: 4-year results. Am J Dent. 2010; 23:34-8. [PMID: 20437725]

5. Gross EL1, Leys EJ, Gasparovich SR, Firestone ND, Schwartzbaum JA, Janies DA, et al. Bacterial 165 sequence analysis of severe caries in young permanent teeth. J Clin Microbiol. 2010; 48:4121-8. [DOl: 10.1128/JCM.01232-10] [PMID: 20826648]

6. Viola NV, Filho MT, Cerri PS. MTA versus Portland cement: review of literature. RSBO Revista Sul-Brasileira de Odontologia. 2011; 8:446-52. 
7. Ito K, Ito S, Shimamura T, Weyand S, Kawarasaki Y, Misaka T, et al. Crystal structure of glucansucrase from the dental caries pathogen Streptococcus mutans. J Mol Biol. 2011; 408(2):177-86. [DOI: 10.1016/j.jmb.2011.02.028] [PMID: 21354427]

8. Do T, Gilbert SC, Clark D, Ali F, Fatturi Parolo CC, Maltz M, et al. Generation of diversity in Streptococcus mutans genes. PLoS ONE. 2010; 5(2):1-8. [DOl: 10.1371/journal.pone.0009073] [PMID: 20140210]

9. Kouidhi B, Zmantar T, Mahdouani K, Hentati H, Bakhrouf A. Antibiotic resistance and adhesion properties of oral Enterococci associated to dental caries. BMC Microbiol. 2011; 11:155. [DOI: 10.1186/1471-2180-11-155] [PMID: 21714920]

10. Sedgley C, Buck G, Appelbe O. Prevalence of Enterococcus faecalis at multiple oral sites in endodontic patients using culture and PCR. J Endod. 2006, 32:104-9. [DOI: 10.1016/j.joen.2005.10.022] [PMID: 16427455]

11. Estrela CR, Pimenta FC, Alencar AH, Ruiz LF, Estrela C. Detection of selected bacterial species in intraoral sites of patients with chronic periodontitis using multiplex polymerase chain reaction. J Appl Oral Sci. 2010; 18:426-31. [DOl: 10.1590/S1678-77572010000400018] [PMID: 20835581]

12. Parolia A, Kundabala M, Rao NN, Acharya SR, Agrawal P, Mohan M, et al. A comparative histological analysis of human pulp following direct pulp capping with Propolis, mineral trioxide aggregate and Dycal. Aust Dent J. 2010; 55:59-64.

[DOI: 10.1111/j.1834-7819.2009.01179.x] [PMID: 20415913]

13. Furey A, Hjelmhaug J, Lobner D. Toxicity of Flow Line, Durafill VS, and Dycal to dental pulp cells: effects of growth factors. J Endod. 2010; 36:1149-53. [DOI: 10.1016/j.joen.2010.03.013] [PMID: 20630288]

14. Spratt DA. Significance of bacterial identification by molecular biology methods. Endod Topics. 2004; 9:5-14. [DOI: 10.1111/j.1601-1546.2004.00106.x

15. Bjørndal L, Reit C, Bruun G. Treatment of deep caries lesions in adults: randomized clinical trials comparing stepwise vs. direct complete excavation, and direct pulp capping vs. partial pulpotomy. Eur J Oral Sci. 2010; 118:290-7.

[DOI: 10.1111/j.1600-0722.2010.00731.x] [PMID: 20572864]

16. Maeda T, Kitasako Y, Senpuku H, Burrow MF, Tagami J. Role of streptococci in the $\mathrm{pH}$-dependent carious dentin. J Med Dent Sci. 2006; 53:159-66

17. Izawa A, Ishihara Y, Mizutani H, Kobayashi S, Goto H, Okabe E, et al. Inflammatory bone loss in experimental periodontitis induced by Aggregatibacter actinomycetemcomitans in interleukin-1 receptor antagonist knockout mice. Infect Immun. 2014; 82:1904-13.

[DOI: 10.1128/IAI.01618-13] [PMID: 24566623]

18. Živković-Sandić M, Popović B, Čarkić J, Nikolić N, Glišić B. Changes in subgingival microflora after placement and removal of fixed orthodontic appliances. Srp Arh Celok Lek. 2014; 142(5-6):301-5. [DOI: 10.2298/SARH1406301Z] [PMID: 25033585]
19. Milićević R, Brajović G, Nikolić-Jakoba N, Popović B, Pavlica D, Leković $V$, et al. Identification of periodontopathogen microorganisms by PCR technique. Srp Arh Celok Lek. 2008; 136(9-10):476-80. [DOI: 10.2298/SARH0810476M] [PMID: 19069337]

20. Martin FE, Nadkarni MA, Jacques NA, Hunter N. Quanittative microbiological study of human cariosus dentine by culture and real-time PCR: association of an aerobes with histhopathological changes in chronic pulpits. J Clin Microbiol. 2002; 40:1698-704. [DOI: 10.1128/JCM.40.5.1698-1704.2002] [PMID: 11980945]

21. Kneist S, Heinrich-Welzien R. Antibacterial action of CARISOLVTM In: Albreksston T. Tissue Preservation in Caries Tretment. London: Quintessence; 2001. p.205-19.

22. Aas JA, Griffen AL, Dardis SR, Lee AM, Olsen I, Dewhirst FE, et al. Bacteria of dental caries in primary and permanent teeth in children young adults. J Clin Microbiol. 2008; 46:1407-17. [DOI: 10.1128/JCM.01410-07] [PMID: 18216213]

23. Cheon K, Moser SA, Whiddon J, Osgood RC, Momeni S, Ruby JD, et al. Genetic diversity of plaque mutans streptococci with rep-PCR. J Dent Res. 2011; 90:331-5. [DOI: 10.1177/0022034510386375] [PMID: 21297016]

24. Duque C, Negrini Tde C, Sacono NT, Spolidorio DM, de Souza Costa CA, Hebling J. Clinical and microbiological performance of resin-modified glass-ionomer liners after incomplete dentine caries removal. Clin Oral Invest. 2009; 13:465-71. [DOI: 10.1007/s00784-009-0304-2] [PMID: 19548010]

25. Perez F, Rochd T, Lodter JP, Calas P, Michel G. In vitro study of the penetration of three bacterial strains into root dentine. Oral Surg Oral Med Oral Pathol. 1993; 76:97-103. [DOI: 10.1016/0030-4220(93)90302-K] [PMID: 8351128]

26. Love RM. Enterococcus faecalis - a mechanism for its role in endodontic failure. Int Endod J. 2001; 34:399-405. [DOI: 10.1046/j.1365-2591.2001.00437.x] [PMID: 11482724]

27. Kayaoglu G, Ørstavik D. Virulence factors of Enterococcus faecalis: relationship to endodontic disease. Crit Rev Oral Biol Med. 2004; 15:308-20. [DOI: 10.1177/154411130401500506] [PMID: 15470268]

28. Kolenbrander PE, Palmer RJ Jr, Periasamy S, Jakubovics NS. Oral multispecies biofilm development and the key role of cell-cell distance. Nat Rev Microbiol. 2010; 8(7):471-80. [DOI: 10.1038/nrmicro2381] [PMID: 20514044]

29. Gomes BPFA, Souza SFC, Ferriz CC, Teixeira FB, Zaia AA, Valdrighi $L$, et al. Effectiveness of $2 \%$ chlorhexidine gel and calcium hydroxide against Enterococcus faecalis in bovine root dentine in vitro. Int Endod J. 2002; 36:267-75. [DOI: 10.1046/j.1365-2591.2003.00634.X] [PMID: 12702121]

Received: 03/09/2015 • Accepted: 11/01/2016 


\title{
Analiza mikrobiološkog statusa dubokih karijesnih lezija
}

\author{
Irena Kuzmanović Radman', Aleksandra Đeri', Adriana Arbutina², Jelena Milašin ${ }^{3}$ \\ ${ }^{1}$ Katedra za bolesti zuba, Medicinski fakultet, Studijski program Stomatologija, Univerzitet u Banjoj Luci, Banja Luka, \\ Republika Srpska, Bosna i Hercegovina; \\ ${ }^{2}$ Katedra za ortopediju vilica, Medicinski fakultet, Studijski program Stomatologija, Univerzitet u Banjoj Luci, Banja Luka, \\ Republika Srpska, Bosna i Hercegovina; \\ ${ }^{3}$ Univerzitet u Beogradu, Stomatološki fakultet, Beograd, Srbija
}

\begin{abstract}
KRATAK SADRŽAJ
Uvod Karijes je jedno od najznačajnijih i najrasprostranjenijih oboljenja usne duplje. Danas je sigurno da su dentalni plak, odnosno mikroorganizmi u njemu, najvažniji faktor nastanka karijesa. Caries profunda je duboka karijesna lezija koja predstavlja mesto odakle bakterijsko-toksični agensi preko dentinskih kanalića ugrožavaju pulpu. Cilj ovog rada je bio da se na osnovu mikrobiološke analize bakterija zastupljenih u karijesnoj leziji pre i posle terapije, odnosno na osnovu kliničkih istraživanja proveri efikasnost lečenja dubokih karijesnih lezija indirektnim prekrivanjem pulpe.

Materijal i metode rada Kliničko istraživanje je obuhvatilo 29 pacijenata oba pola, uzrasta od 16 do 40 godina, odnosno 45 stalnih zuba sa dubokim karijesnim lezijama. Posle preparacije kaviteta i uklanjanja razmekšalog dentina, sa dna kaviteta je uzet prvi bris. Drugi bris je uzet posle delovanja i uklanjanja privremenog ispuna i paste kalcijum-hidroksida nakon 60 dana. Uzeti brisevi su odloženi u posebne sterilne mikrotubice (ependorfe) i čuvani na temperaturi od $-80^{\circ} \mathrm{C}$ do mikrobiološke analize. Uzorci materijala su ispitani na prisustvo sledećih mikroorganizama: Porphyromonas gingivalis, Aggregatibacter actinomycetemcomitans i Enterococcus faecalis primenom metode multipleks tehnika reakcije lančanog umnožavanja DNK (engl. polymerase chain reaction - PCR).

Rezultati Rezultat je pokazao da je pre početka lečenja dubokih karijesnih lezija najčešća bakterija bila $E$. faecalis (80\% uzoraka), potom A. actinomycetemcomitans (32\% uzoraka), dok je najređa bila bakterija $P$. gingivalis (16\% uzoraka). Nakon sprovedene terapije preparatima na bazi kalcijum-hidroksida, E. faecalis je zabeležen u $18 \%$ uzoraka, a A. actinomycetemcomitans u $16 \%$, dok $P$. gingivalis nije registrovan ni u jednom uzorku.

Zaključak U zubima sa dubokim karijesnim lezijama najčešća bakterija bila je E. faecalis, potom A. actinomycetemcomitans, a u najmanjem broju uzoraka je ustanovljen $P$. gingivalis.

Ključne reči: duboki karijes; bakterije; indirektno prekrivanje
\end{abstract}

\section{UVOD}

Karijes je sigurno jedno od najznačajnijih oboljenja usne duplje i široko je rasprostranjeno i kod dece i kod odraslih $[1,2,3]$. Caries profunda (duboki kvar zuba) je mesto odakle bakterijsko-toksični agensi preko dentinskih kanalića ugrožavaju pulpu, uslovljavajući manje ili veće promene u njoj. Mogućnost zaustavljanja daljeg širenja lezije postoji ukoliko se bakterije uklone ili „zarobe“ u kavitetu nakon restauracije. Tubularna skleroza i tercijarni dentin ih mogu izolovati jer je sprečena njihova mogućnost ishrane iz pulpe zbog manje permeabilnosti dentina. Poznato je takođe da zarobljeni mikroorganizmi u kavitetu mogu da se menjaju i da pri tom postaju manje patogeni [4].

Danas je sigurno da su dentalni plak (biofilm), odnosno mikroorganizmi koji se nalaze u njemu, najvažniji faktor nastanka karijesa. Zbog vrlo kompleksne etiologije i patogeneze ovog oboljenja, njegova terapija je i dalje značajan problem za većinu stomatologa praktičara. U zubnom plaku je osim Streptococcus mutans, Lactobacillus spp. i Actinomyces spp. moguće otkriti i prisustvo piogenih bakterija, kao što su Porphyromonas gingivalis, Prevotella intermedia i Aggregatibacter actinomycetemcomitans [5].

Viola (Viola) i saradnici [6] su u svojoj studiji, na osnovu uzoraka iz pljuvačke uzetih od dece s karijesnim lezijama i bez ovih lezija, utvrdili da karijes započinje onda kada glukan-polimer glukoze (stvara ga $S$. mutans) formira na površini zuba biofilm na koji prianjaju oralne bakterije, ostaci hrane i komponente iz pljuvačke. Do istog zaključka su došli i Ito (Ito) i saradnici [7] bez obzira na drugačiju metodologiju tokom istraživanja. Do (Do) i saradnici [8] su utvrdili da je S. mutans najčešeći uzročnik nastanka dentalnog karijesa. Kuidi (Kouidhi) i saradnici [9] su u svojim iskazima potvrdili prisustvo enterokokusa u usnoj duplji dece u Tunisu. Oni su izolovali 33,9\% enterokokusa od svih pozitivnih koka identifikovanih iz oralne duplje, pri čemu je 55,8\% enterokokusa izolovano iz karijesnih lezija, a samo $2 \%$ iz usne duplje dece bez karijesa.

Za očuvanje vitaliteta pulpe i uspešnu terapiju dubokog karijesa neophodni su pravovremena i pravilna dijagnoza, brzo i efikasno uklanjanje karijesno promenjenog dentina (kao osnovnog rezervoara mikroorganizama), primena odgovarajućih medikamenata i kvalitetna restauracija kaviteta [10]. Medikamentna sredstva koja se koriste u lečenju dubokog karijesa imaju zadatak da deluju na zaostale mikroorganizme, ali i da stimulišu odontoblaste na stvaranje tercijarnog dentina. Preparati na bazi kalcijum-hidroksida su najčešće korišćena sredstva u lečenju dubokog karijesa iako se poslednjih godina u ove svrhe sve više koristi i MTA s vrlo visokim procentom uspešnosti [11]. Aplikovani na dno preparisanog kaviteta, ovi materijali stimulišu odontoblaste na proizvodnju reparativnog dentina, ali deluju i antibakterijski na zaostale mikroorganizme u tankom sloju sačuvanog dentina.

Mišljenja autora o terapiji dubokog karijesa i danas su podeljena. Jedni smatraju da je pre primene medikamentnih sredstava neophodno potpuno ukloniti karijesno promenjeni dentin, dok drugi zagovaraju pristup sa delimičnim uklanjanjem razmekšalog dentina, te ostavljanjem tankog sloja dentina na dnu preparisanog kaviteta. Bez obzira na veliki napredak moderne stomatologije i veliki broj medikamentnih sredstava koji se danas koriste u lečenju karijesa, terapija dubokog karijesa se i dalje smatra složenim postupkom čiji uspeh zavisi od brojnih faktora $[4,12,13,14]$.

Cilj ovog istraživanja bio je da se na osnovu mikrobiološke analize bakterija u karijesnoj leziji, pre i posle terapije, odnosno 
na osnovu kliničkih istraživanja, proveri efikasnost lečenja dubokih karijesnih lezija postupkom indirektnog prekrivanja pulpe.

\section{MATERIJAL I METODE RADA}

Kliničko istraživanje je obuhvatilo 29 pacijenata oba pola, uzrasta od 16 do 40 godina, kod kojih je na osnovu anamneze, kliničkog i radiografskog pregleda 45 zuba dijagnostikovan duboki karijes. Za evidentiranje dobijenih podataka ovog istraživanja napravljen je poseban karton za svakog pacijenta, gde su upisani lični podaci, podaci o stanju zuba i precizni podaci o lekovima i materijalima, zastupljenosti bakterija u uzetim brisevima, odnosno o subjektivnim i objektivnim promenama tokom terapijskog protokola.

Posle preparacije kaviteta i uklanjanja razmekšalog dentina, sa dna kaviteta je uzet prvi uzorak za mikrobiološku analizu. Uzorak je uzet sterilnom kuglicom vate i sterilnom pincetom, a potom odložen u posebne sterilne mikrotubice (ependorfe) sa $150 \mathrm{ml}$ transportne tečnosti i čuvan na temperaturi od $-80^{\circ} \mathrm{C}$ do mikrobiološke analize. Metodom slučajnog izbora kod pacijenta je u očišćeni kavitet aplikovano sredstvo na bazi kalcijum-hidroksida (Dycal, DENTSPLY, Nemačka, ili Calcipulpe, Septodont, Francuska), a potom je kavitet ispunjen materijalom za privremeno zatvaranje (fosfatnim cementom, Galenika, Srbija) tokom dva meseca. Nakon dva meseca iz kaviteta su uklonjeni privremeni ispun i preparat na bazi kalcijum-hidroksida, a sa dna kaviteta uzet je drugi mikrobiološi uzorak sterilnom vaticom i sterilnom pincetom.

Izolacija eventualno prisutne bakterijske DNK vršena je tretiranjem uzoraka proteinazom $\mathrm{K}$ na temperaturi od $56^{\circ} \mathrm{C}$ tokom 30 minuta, nakon čega je sledila inaktivacija enzima zagrejavanjem uzoraka na temperaturi od $94^{\circ} \mathrm{C}$ tokom 15 minuta. Tako pripremljeni materijal čuvan je na $-20^{\circ} \mathrm{C}$ do kompletne PCR analize. Uzorci materijala su ispitani na prisustvo sledećih mikroorganizama: Porphyromonas gingivalis, Aggregatibacter actinomycetemcomitans i Enterococcus faecalis. Za izvođenje PCR reakcije korišćene su poznate sekvence prajmera.

\section{REZULTATI}

Analiza mikroorganizama u biološkom materijalu uzetom iz 45 zuba (pri čemu je broj analiziranih zuba po pacijentu varirao od 1 do 4) pokazala je da je najčešći bio E. faecalis (80\%), potom $A$. actinomycetemcomitans (32\%), dok je najređi bio $P$. gingivalis (16\%).

Postojanje elektroforetskih traka očekivane dužine na poliakrilamidnom gelu označavalo je pozitivan nalaz za ispitivanu bakteriju. Na slici 1 prikazan je gel sa odabranim uzorcima $E$. faecalis. Jasno se vidi da je kod jednog pacijenta ova bakterija otkrivena u sva četiri analizirana zuba (1a, 1b, 1c, 1d), s tim da je u uzorku 1d verovatno bila nešto ređa (PCR je samo semikvantitativna tehnika). Kod drugog pacijenta (2a, 2b, 2c) u sva tri ispitana zuba takođe je otkrivena ova bakterija, dok je kod jednog pacijenta $(8 \mathrm{a}, 8 \mathrm{~b}, 8 \mathrm{c})$ uočena samo u uzorku $8 \mathrm{~b}$.

Na slici 2 prikazan je poliakrilamidni gel s odabranim uzorcima pozitivnim na A. actinomycetemcomitans. Nivo amplifikacije je bio prilično ujednačen u većini uzoraka, što je relativno neuobičajno za PCR reakcije na bakterijskim izolatima iz zuba.
Ako se posmatra incidencija infekcija, kod 17 pacijenata otkrivena je bar jedna ispitivana bakterija (Tabela 1). Kod tri pacijenta ustanovljena je koinfekcija sve tri bakterije. Zanimljivo je da su sva tri pacijenta bila ženskog pola. Takođe, kod dva pacijenta ustanovljene su istovremeno E. faecalis i A. actinomycetemcomitans, dok su kod po jednog pacijenta zabeleženi istovremeno $P$ gingivalis i A. actinomycetemcomitans, kao i $E$. faecalis i $P$. gingivalis.

Analiza postojanja mikroorganizama u brisevima nakon primenjene terapije pokazala je da se učestalost sve tri bakterije značajno smanjila. Kod E. faecalis (16\%) i P. gingivalis (0\%) to smanjenje je bilo visoko statistički značajno ( $\mathrm{p}<0,05)$, dok kod A. actinomycetemcomitans nije bilo (Tabela 2 ).

\section{DISKUSIJA}

Karijes je jedno od najznačajnijih i najrasprostranjenijih oboljenja usne duplje. Zbog njegove vrlo složene etiologije i patogeneze, lečenje je i dalje značajan problem i često s vrlo neizvesnim ishodom.

Bjorndal (Bjørndal) i saradnici [15] su u svome istraživanju izvedenom na 314 pacijenata na Stomatološkom fakultetu u Kopenhagenu utvrdili da su zubi bočnog segmenta bili češće zahvaćeni dubokim karijesom u odnosu na frontalne zube. S prethodnim istraživanjem su se složili i Ahmad (Ahmad) i saradnici [1], koji su realizovali istraživanje na 204 zuba sa dubokim karijesom (21 zub su činili sekutići, a 183 zubi bočnog segmenta).

Maeda (Maeda) i saradnici [16] su ispitivali uticaj oralnih streptokoka i laktobacila na nivo pH u aktivnoj karijesnoj leziji kod 24 ekstrahovana humana molara inficirana karijesom i zaključili da je $\mathrm{pH}$ vrednost dentina zahvaćenog karijesom bila niža od $\mathrm{pH}$ vrednosti intaktnog dentina. Takođe su zaključili da postoji značajna korelacija između sniženja $\mathrm{pH}$ vrednosti i demineralizacije u aktivnim karijesnim lezijama. Koristeći PCR metodu i pH-imidžing mikroskop, ovi autori su utvrdili da je najniža $\mathrm{pH}$ vrednost registrovana u uzorcima dentina zahvaćenim aktivnim karijesnim lezijama u kojima su otkriveni $S$. mutans i veliki broj drugih oralnih bakterija. U sedam od osam uzoraka s najvišim $\mathrm{pH}$ vrednostima autori su zabeležili postojanje samo S. mutans, koji formira biofilm i započinje dentinsku destrukciju zajedno sa drugim bakterijama koje stvaraju aktivnu karijesnu leziju [16].

Estrela (Estrela) i saradnici [11] su ispitivali dejstvo nekoliko lekova koji se koriste u terapiji dubokog karijesa. Istražujući antimikrobni efekat MTA, Portland cementa, Dycal, paste na bazi kalcijum-hidroksida, i Sealapeax na nekoliko vrsta bakterija (Enterococcus faecalis, Pseudomonas aeruginosa, Bacillus subtilis, Staphylococcus aureus) i gljivicu (Candida albicans). Posle dvodnevnog inkubacionog perioda ustanovili su da je pasta na bazi kalcijum-hidroksida imala najveće antimikrobno dejstvo i najbolji terapijski učinak (izmerena zona inhibicije je bila 6-9,5 $\mathrm{mm}$, a zona difuzije $10-18 \mathrm{~mm}$ ). Rezultati za pastu Dycal su pokazali da nije bilo ni zone inhibicije, niti zone difuzije, što je ukazivalo na slabo antimikrobno dejstvo. Parolija (Parolia) i saradnici [12] su u svome istraživanju na 36 premolara takođe potvrdili rezultate prethodnih autora.

Dobro prianjanje materijala za zidove kaviteta fizički sprečava prodor bakterija ka pulpi i važan je preduslov za uspeh 
lečenja indirektnog prekrivanja pulpe. Međutim, s obzirom na to da danas ne postoji nijedan materijal koji obezbeđuje odgovarajuće rubno zatvaranje, veoma je važno da se u restaurativnoj proceduri koriste materijali sa dobrim adhezivnim svojstvima i tehnike restauracije koje će obezbediti dobru adhezivnu vezu materijala sa zidovima kaviteta.

U zubnom plaku je takođe moguće otkriti piogene bakterije, kao što su Porphyromonas gingivalis, Prevotella intermedia i Aggregatibacter actinomycetemcomitans [18, 19]. Pored anaerobnog kultivisanja mikroorganizama primenjuju se i testovi za otkrivanje njihovih antigena, kao što je tehnika hibridizacije, odnosno PCR metoda identifikacije, koja je korišćena i u ovom radu [5]. Istraživanja Martina (Martin) i saradnika [20] na 65 zuba sa dubokim karijesnim lezijama i upaljenom pulpom pokazala su (na osnovu PCR metode) da anaerobne bakterije imaju važnu ulogu u nastanku karijesa i endodontske infekcije. Knajst (Kneist) i saradnici [21] su uklanjali karijesne mase na mlečnim zubima hemomehaničkom metodom (CARISOLV ${ }^{\mathrm{TM}}$ sistemom) a zatim uzimali bris sa dna kaviteta za mikrobiološku analizu. Utvrdili su da je broj bakterija kod dubokog karijesa znatno veći nego u brisevima uzetim iz plićih karijesnih destrukcija (caries media). Oni su takođe identifikovali bakterijske sojeve u preparisanom kavitetu, gde su najčešće bile oralne streptokoke (S. mutans, S. intermedia itd.), zatim vrste roda Actinomyces, kao i vrste roda Lactobacillus [21].

As (Aas) i saradnici [22] su izveli istraživanje kod 90 ispitanika (51 sa dubokim karijesom i dijagnostikovanim pulpitisom).Zasejavanjem na bakterijskim kulturama i PCR metodom procenili su učestalost anaerobnih bakterija i zaključili da bakterije Veillonella, Lactobacillus, Bifidobacterium i Propionibacterium, Actinomyces spp. i Atopobium spp, uz S. mutans, imaju važnu ulogu u razvoju karijesa. Čeon (Cheon) i saradnici [23] su koristeći PCR metodu na 20 uzoraka dentalnog plaka kod ispitanika različite starosne dobi (dece uzrasta od pet do šest godina i odraslih) zaključili da je veći broj genotipova bakterije $S$. mutans (u rasponu od 1,6 do $2,4)$ bio češći kod dece nego kod odraslih ispitanika.

Dik (Duque) i saradnici [24] su ispitivali efekte glasjonomercementa (Fuji) i paste Dycal u terapiji dubokog karijesa na 27 stalnih molara. Primenom PCR metode utvrđene su bakterijske vrste $S$. mutans i Lactobacillus pre i tri meseca posle lečenja dubokog karijesa. Utvrđeno je značajno smanjenje broja ovih bakterija u uzorcima.

Potvrđeno je da je 90\% enterokoknih infekcija kod čoveka izazvano s E. faecalis. Ova bakterija može da preživi u ekstremno teškim uslovima, jer se može prilagoditi različitim uslovima sredine. Ona postaje manje osetljiva na letalne doze vodonik- peroksida i etanola, te na promene $\mathrm{pH}$ sredine. Studije Pereza (Perez) i saradnika [25] i Lava (Love) i saradnika [26] su pokazale da se E. faecalis nalazi u dentinskim tubulima zuba s karijesnim lezijama, što je jedan od razloga izvođenja i naše studije. Kajaoglu (Kayaoglu) i Orstavik (Ørstavik) [27] su ukazali na veliki značaj E. faecalis u nastanku endodontskih oboljenja i periapikalnih zapaljenja. Kolenbrander (Kolenbrander) i saradnici [28] su ispitujući bakterije u dentalnom plaku (biofilmu), kao jednom od najznačajnijih faktora u nastanku karijesa, uočili i postajanje A. actinomycetemcomitans i $P$. gingivalis. Gomez (Gomez) i saradnici [29] su ispitujući uticaj hlorheksidina i kalcijum-hidroksida na 180 intaktnih goveđih zuba inficiranih sa E. faecalis zaključili da hlorheksidin potpuno inhibira rast ove bakterije, dok kalcijum-hidroksid nije imao uticaja na njen rast.

Analiza briseva uzetih od pacijenata u ovom istraživanju pre početka lečenja pokazala je da je najčešća bakterija bila $E$. faecalis, zatim A. actinomycetemcomitans i P. gingivalis. Nakon primenjene terapije preparatima na bazi kalcijum-hidroksida, došlo je do značajnog smanjenja broja E. faecalis i A. actinomycetemcomitans u tretiranim uzorcima, dok $P$. gingivalis nije zabeležen ni u jednom uzorku. Ovo smanjenje broja bakterije $E$. faecalis može se objasniti činjenicom da je E. faecalis verovatno efikasno mehanički uklonjen rotirajućim instrumentima ili je difundovao u dentinske tubule. Drugi razlog što nije uočen na dnu kaviteta mogao bi biti dobro rubno zatvaranje fosfatnim cementom nakon primene medikamenta na bazi kalcijum-hidroksida tokom 60 dana. S obzirom na to da preparati na bazi kalcijum-hidroksida nemaju izrazit efekat na $E$. faecalis, njegovo smanjenje je verovatno posledica korektnog mehaničkog ukljanjanja karijesnih masa i dobrog restaurativnog ispuna koje je realizovao isti terapeut u odgovarajućim kliničkum uslovima. Zaostajanje E. faecalis u dubljim slojevima dentinskih tubula i neefikasno ukljanjanje karijesa mogu biti i razlog neuspeha indirektnog prekrivanja pulpe, što posledično može dovesti do upale pulpe i zahteva za endodontskom intervencijom na oboleloj pulpi.

\section{ZAKLJUČAK}

Pre početka lečenja dubokih karijesnih lezija najčešća bakterija je bila E. faecalis, potom A. actinomycetemcomitans, dok je najređa bila $P$. gingivalis. Nakon primenjene terapije indirektnog prekrivanja pulpe, E. faecalis i A. actinomycetemcomitans su zabeleženi u značajno manjem broju, a $P$ gingivalis nije otkriven ni u jednom uzorku. 